\title{
Thema: Kwaliteitsbeheersing voor accountants
}

Het accountantsberoep, voorzover dat als vrij beroep wordt uitgeoefend, steunt op twee pijlers: onafhankelijkheid en deskundigheid. Over beide zaken wordt de laatste jaren veel geschreven en gesproken.

De geruchtmakende schandalen van beursgenoteerde ondernemingen worden wel toegeschreven aan de te grote afhankelijkheid van het management en van diverse kanten heeft dit geleid tot voorschriften en maatregelen, die de onafhankelijkheid van de accountant beogen te waarborgen. Niet alleen vanuit het beroep zelf op nationaal en internationaal niveau, maar vooral ook van instanties buiten het beroep, zoals beurstoezichthouders en de wetgever. Eigenlijk is dit een bijzondere ontwikkeling, want als vanouds was zelfregulering de gewoonte binnen het accountantsberoep, met name in Europa.

Blijkbaar zijn voor de samenleving initiatieven door het beroep zelf niet meer voldoende en worden deze niet meer geloofd. Het zou interessant zijn te onderzoeken waarom het tijdperk van zelfregulering op het gebied van onafhankelijkheid tot een einde is gekomen. De redactie van dit maandblad zou een fundamentele beschouwing op dit gebied van harte toejuichen.

Met de deskundigheid zien we een gelijke ontwikkeling. Ook hier werden de eisen gesteld door het beroep zelf en ook de controle hierop werd geregeld door beroepsgenoten. Kwaliteitscontrole of -beheersing was een zaak van het beroep zelf. De laatste tijd zijn ook hier veranderingen te constateren. Kwaliteitsbeheersing is een zaak van buitenstaanders geworden, zodat ook op dit gebied de zelfregulering een einde heeft genomen.

Het thema 'Kwalteitsbeheersing voor accountants' wordt belicht vanuit vier verschillende invalshoeken. Majoor en Wallage behandelen kwaliteitsbeheersingssystemen binnen het accountantsberoep, in het bijzonder in hoeverre aanpassing van het stelsel van kwaliteitstoetsing in Nederland nodig is om te voldoen aan de eisen van wet- en regelgeving en het maatschappelijk verkeer die als gevolg van recente debacles zijn aangescherpt. Zij tonen aan dat het huidige stelsel van kwaliteitstoetsing op een aantal onderdelen niet voldoet aan de eisen die hieraan op basis van regelgeving, maatschappelijke ontwikkelingen en toekomstige samenwerking met de Autoriteit Financiële Markten (AFM) gesteld zouden moeten worden en doen een aantal aanbevelingen die tot verbetering moeten leiden.

In het artikel van Dinant en Maijoor staat de relatie tussen extern onafhankelijk toezicht en de kwaliteit van de accountantscontrole centraal. In Nederland zal naar verwachting in 2006 voor het eerst extern onafhankelijk toezicht van toepassing zijn. De inhoud van de wet waarin het aanstaande toezicht wordt geregeld, wordt besproken, alsmede de relatie tussen extern onafhankelijk toezicht en de bestaande systemen van collegiaal toezicht. De auteurs concluderen dat 'extern onafhankelijk toezicht op de uitvoering van de accountantscontrole bijdraagt aan de kwaliteit van de publieke functie van de externe accountant en daarmee aan het vertrouwen van het publiek in het functioneren van kapitaalmarkten'.

Verkruijsse gaat in op een belangrijke standaard van de International Federation of Accountants (IFAC) die vanaf juni 2005 ook in Nederland van kracht is, en die beoogt de kwaliteit van de accountantscontrole te waarborgen. Hij toont aan dat in deze standaard op alle aan de orde komende gebieden 'kwaliteit in de beroepsuitoefening' het primaat krijgt boven 'productiviteit in de bedrijfsuitoefening.'

Hiermee is volgens deze auteur wederom 'een stapje gezet in het herstellen van het vertrouwen in de kwaliteit van de accountantswerkzaamheden', als onderdeel van een door IFAC nog verder te ontwikkelen kwaliteitsbouwwerk.

Dassen beschrijft de internationale dimensie van de kwaliteitsbeheersing binnen netwerken van accountantsorganisaties. Mede naar aanleiding van de financiële crisis in Zuidoost Azië, en 'geholpen' door de publieke druk als gevolg van de boekhoudschandalen, is de aandacht binnen de netwerken van accountantsorganisaties voor het borgen van kwaliteit van accountantsorganisaties op mondiale schaal enorm toegenomen. Dassen gaat in op de kwaliteitsbeheersing binnen accountancynetwerken en de rol van de International Federation of Accountants.

De redactie hoopt de lezer door deze vier artikelen een overzicht te hebben gegeven van de huidige stand van zaken inzake de kwaliteitsbeheersing voor het accountantsberoep.

Namens de redactie, André Bindenga 